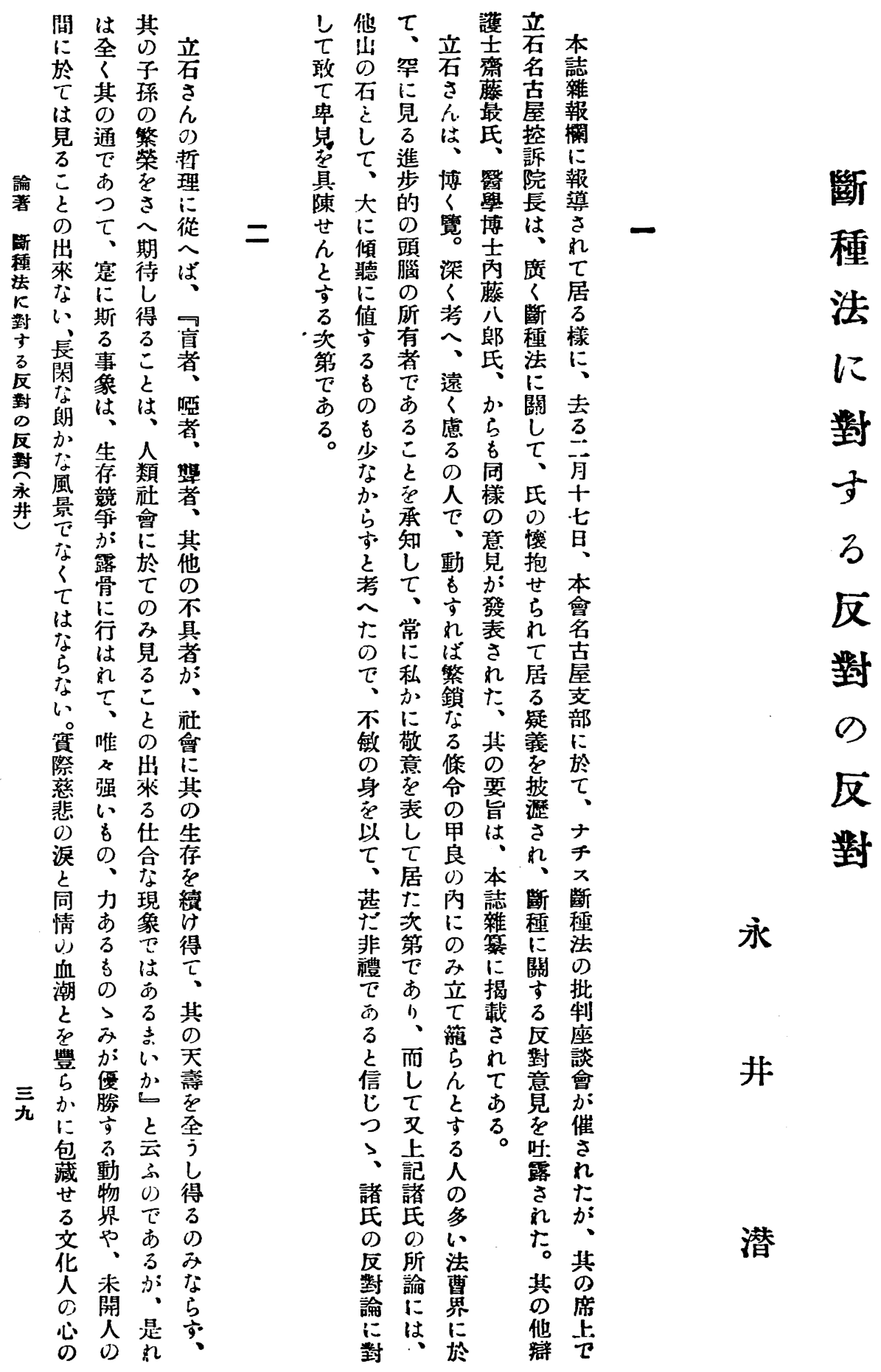




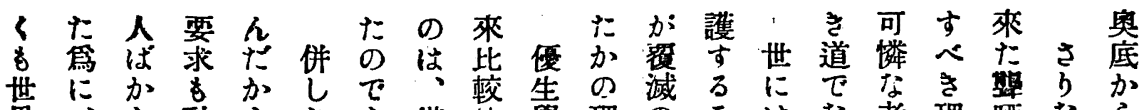

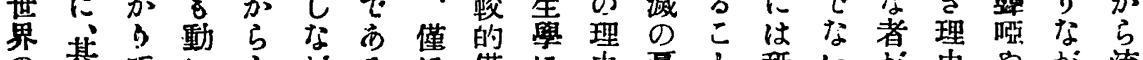

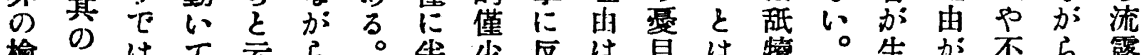

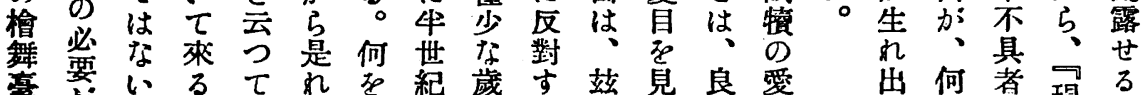

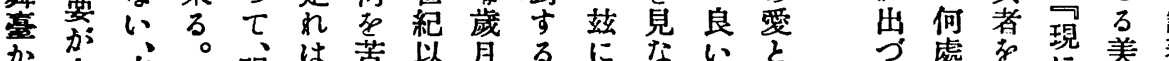

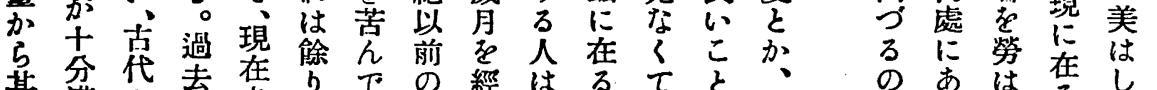
其湳 0 去来

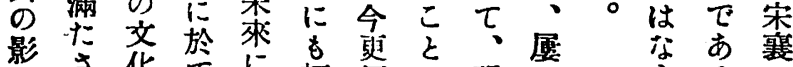

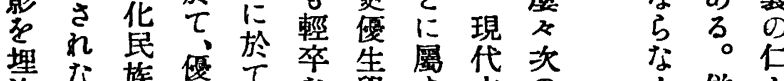

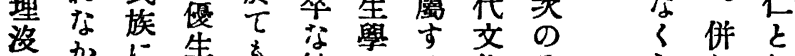

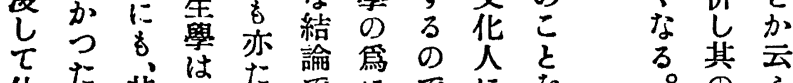

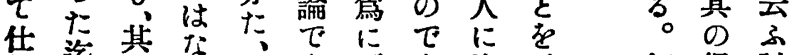

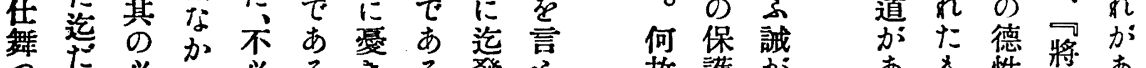

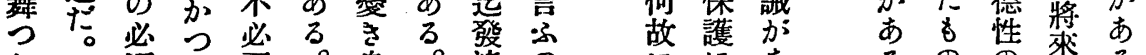

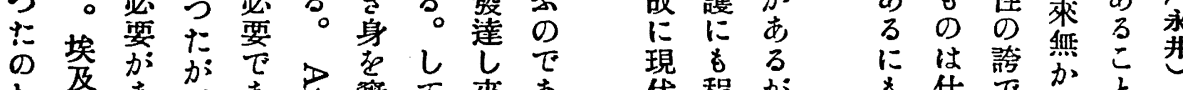

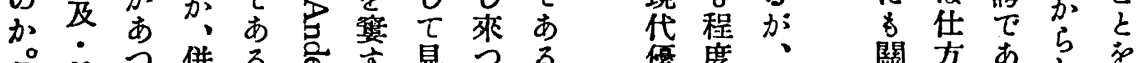

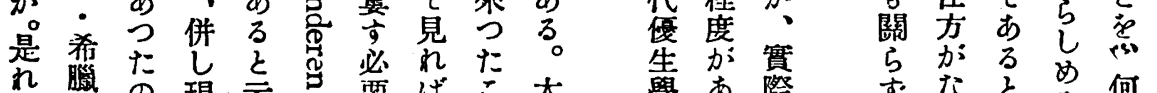

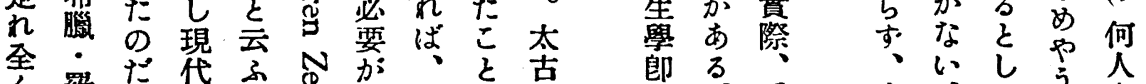

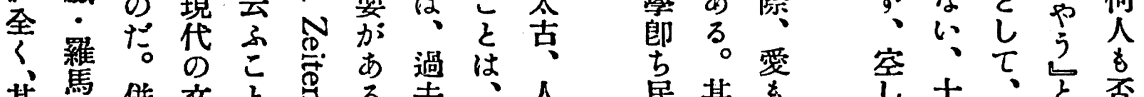

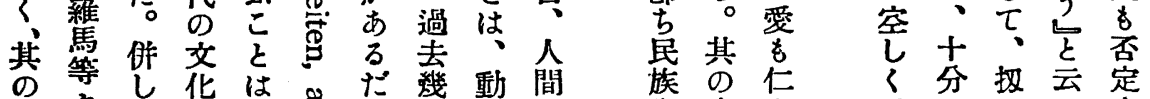

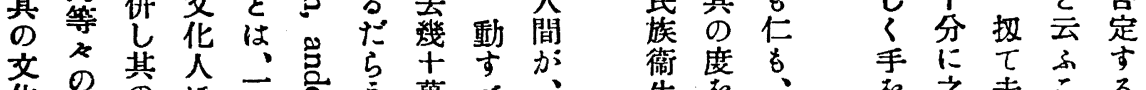

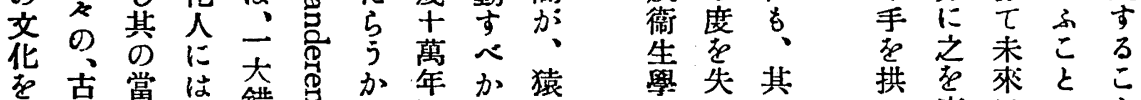

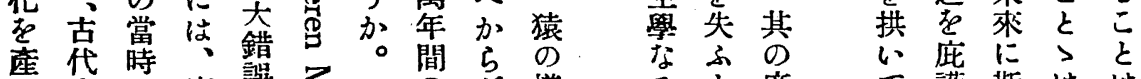

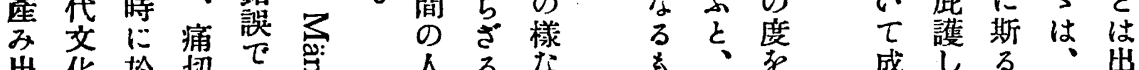

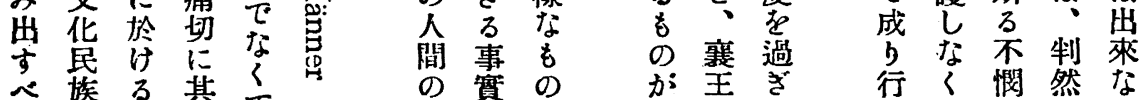

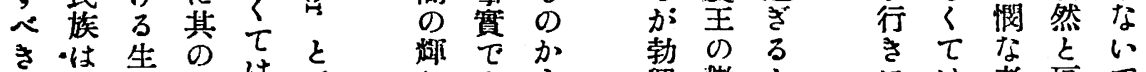

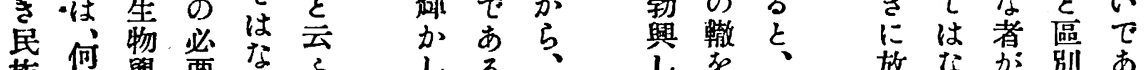

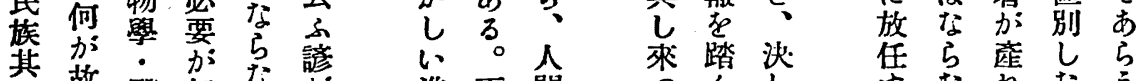

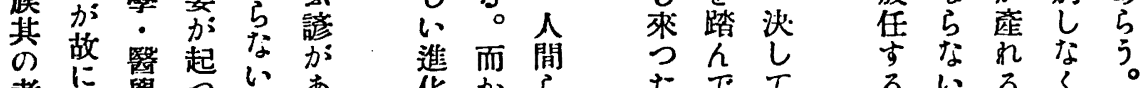

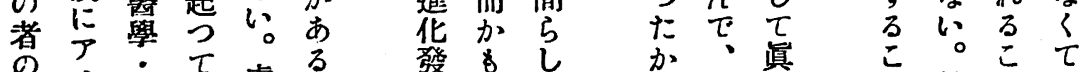

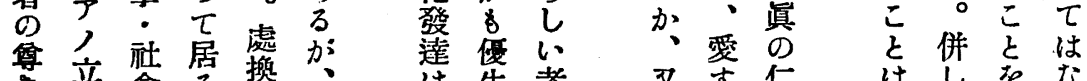

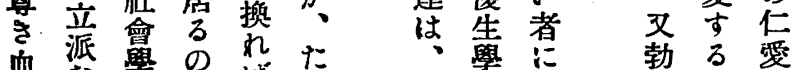

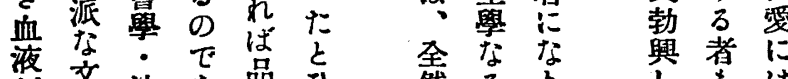

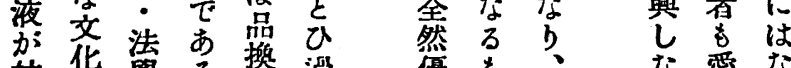

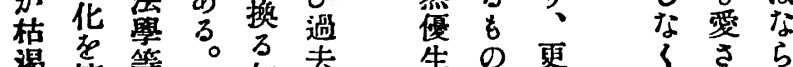

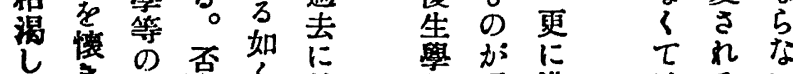

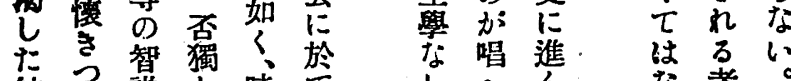

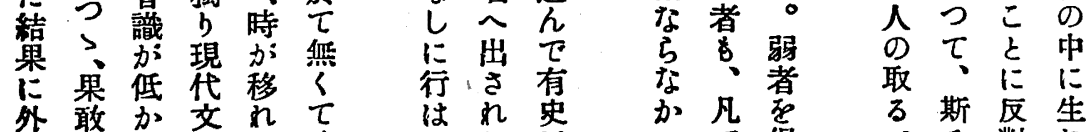

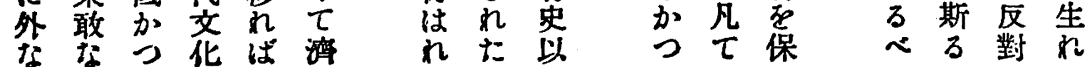




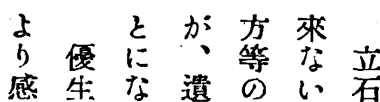

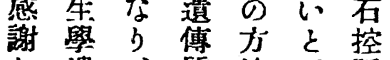

し 遺、筫法云湥

傳私老吢院

止藇共治よこ長

誦まにはすうをに

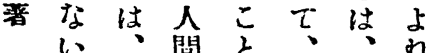

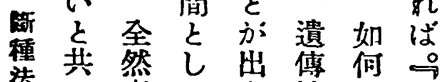

竹素元來性に今

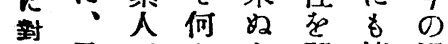

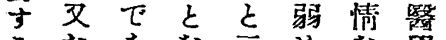

るたあな云めな學

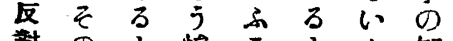

䍌の慘こ文智

反慧名忽とかう識

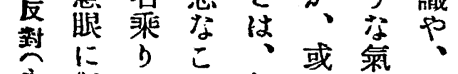

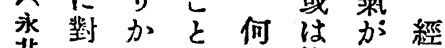

悲

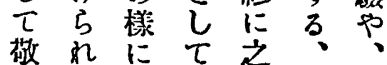

服た思学表一

立 立悲絶代て

万石れし刑芯は

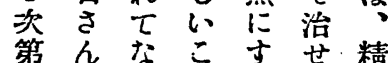

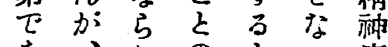

あ、ぬの次病

る斯の樣云も者

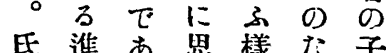

の步るふなら孫

說的气。事心

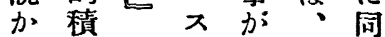

れ極 テ出 數 樣

万的呇來代な

樣のリな艺遺

に激北心治傳

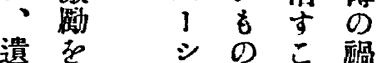

傳、 $、$ 飞害

學遺 ン あ

者傳々 与出受

四

優學云う來河

四生者 ふ加方

學にこ。兄

者與々今あな

はへ 方白方。

万變のう樣

決少若遺吕に

七艺苽隹交方

現占舉配

代は和の宁

る隻取

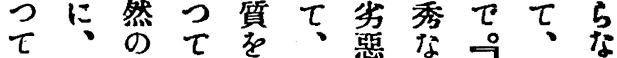

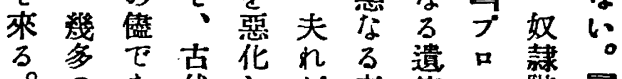

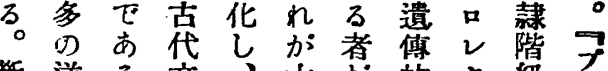

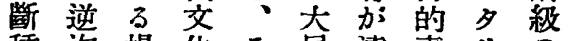

種淘場化こ局遠素》の口

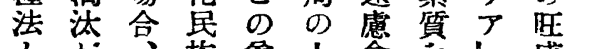

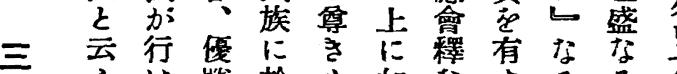

了は勝於心如なするる

これ劣て 融何了范名出な

も、の蝕る級加にる

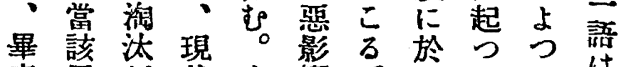

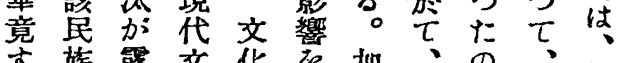

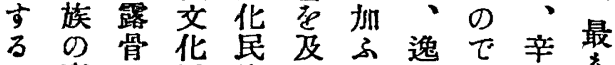

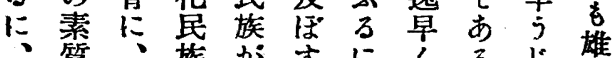

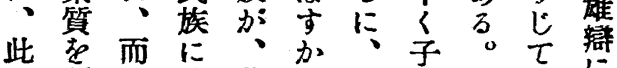

の颓加於花に博供實其に

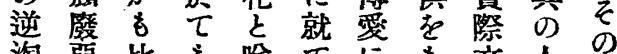

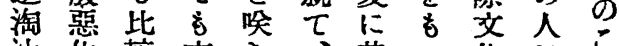

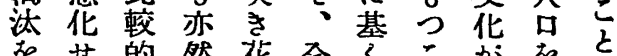

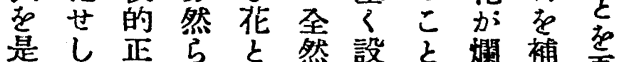

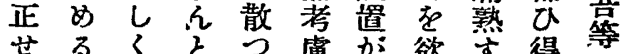

$h こ$ 行して㟲加欲方得に

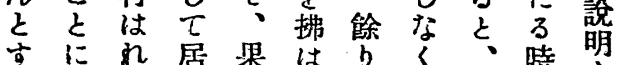

万琼了方敢なにな或代す

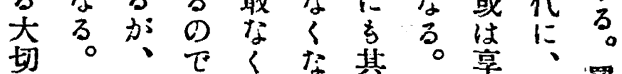

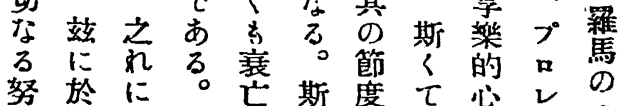

力七反之のく变優理 1 盛

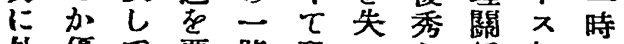

外優て 要路恐うな係即に

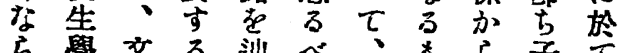

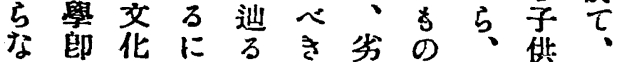

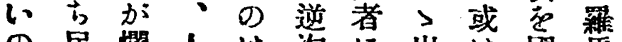

の异橍人は淘に出は國馬

て族熟間、汰對生釈家人

あ衞すの職がすが濟にの

万生了生上、減的提出

學々活し 時保退物供生

必知原是攰灾了關了方

要引始れ合のに係階、

が的に飞子反加釉濑

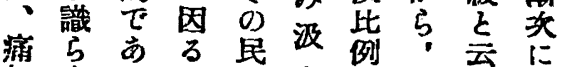

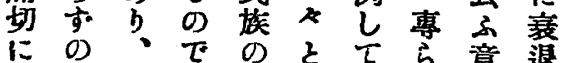

起间自あ素して方意退 
あ賴學所がをの據をれ法成夢明に清あを傅

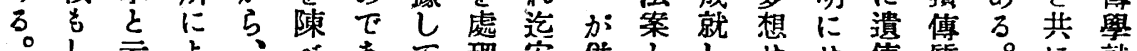

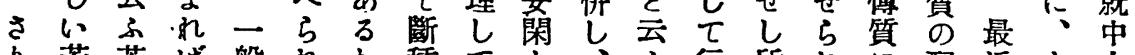

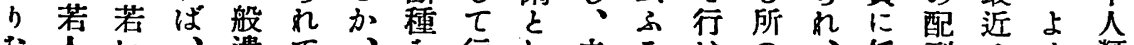
な人い、遺て、蛋行し夫こけの、任列)く類

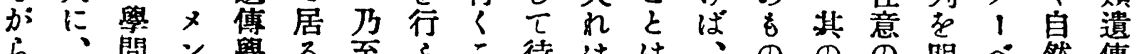
ら、問さ學る至ふこ待はは、ののの明ざ然傳拥

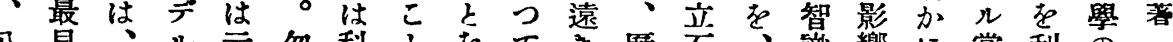

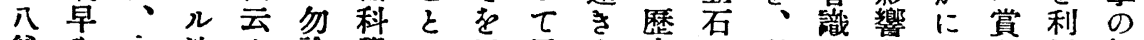

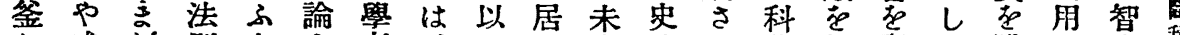

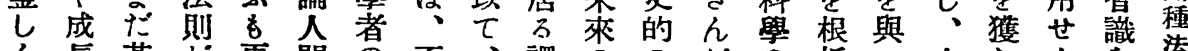

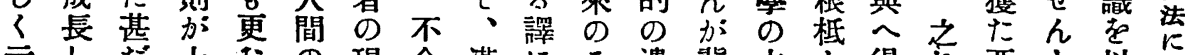
云しだ十なの現合霂にこ遺冀力と得れ惡と以對

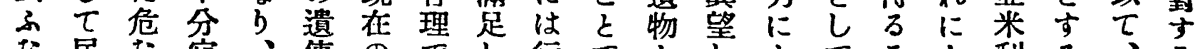
な居な宛、傳のてし行てとしょしてる ら

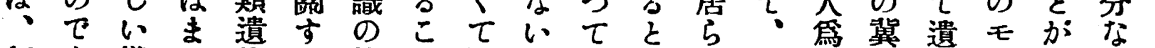

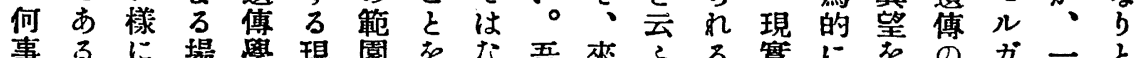

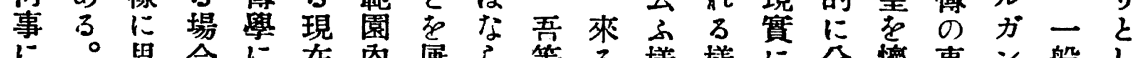

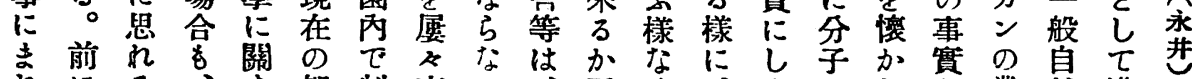

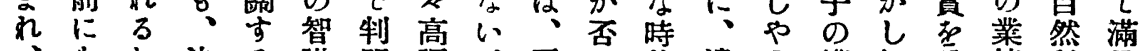

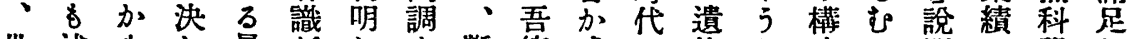

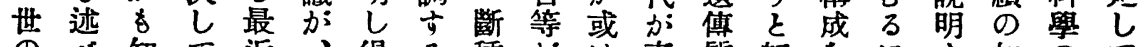
の心知 $\tau$ 近、得る種方は來質努点にす如の元 中たれ少のまな。法現何なの力左至るき大居 に樣な乙集心い立反在時心改し右う起切了

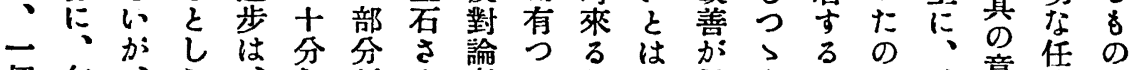

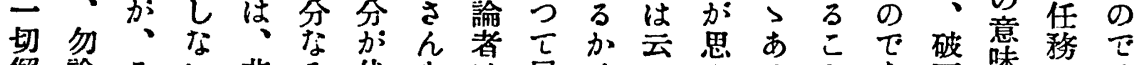

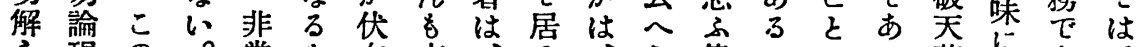
ら現 の

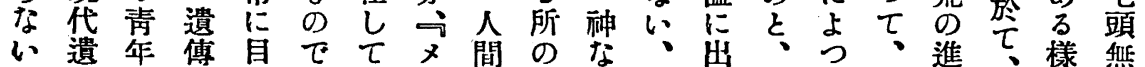

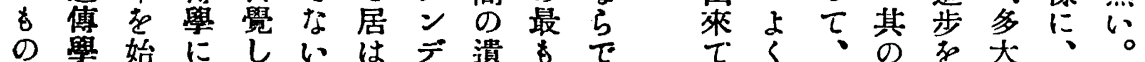

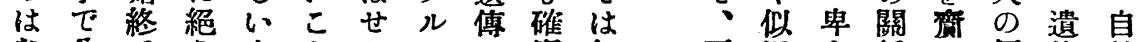

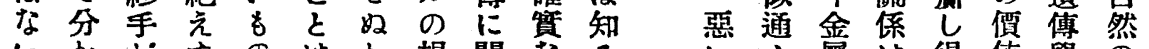

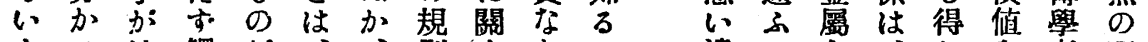

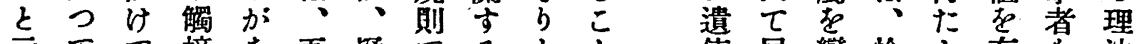

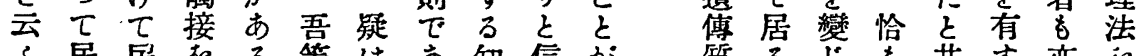

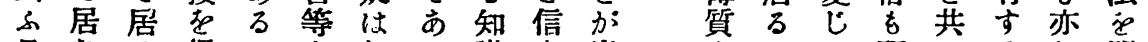

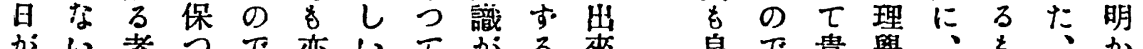

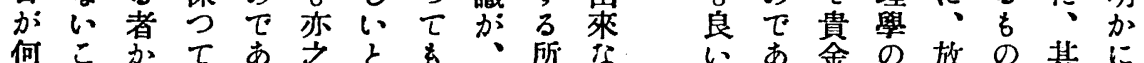

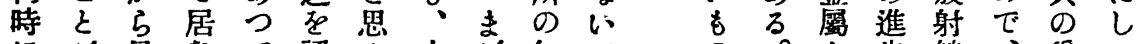

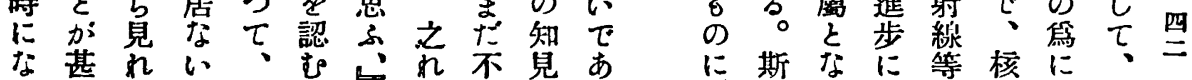

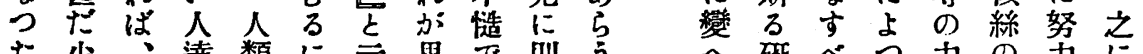
た少

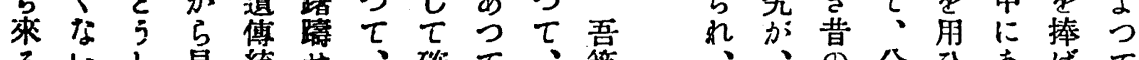

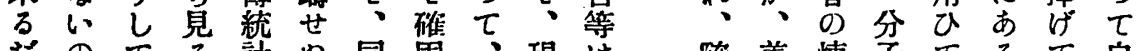

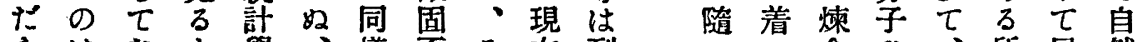

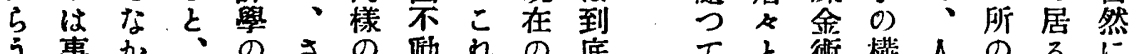

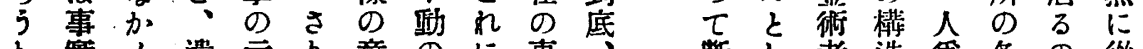

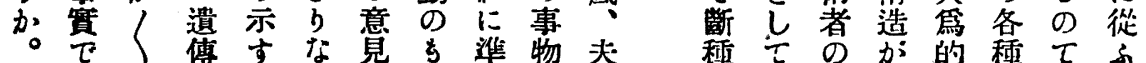




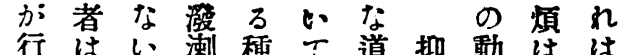

のは論。㵀考德生機さ制石

意れし 其るのへ的物をな官さ

味つ意第保 $\tau$ 信のなけとん

に〉居味三續見條集しれしは

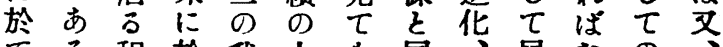
論 $て$ 程於我上む同居なの

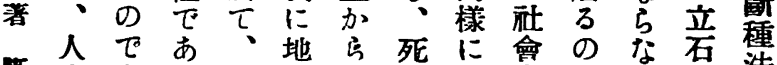

堚生ある各位見と、發てい方法

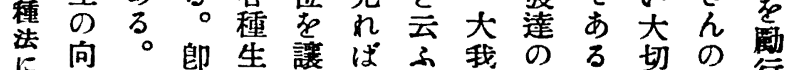

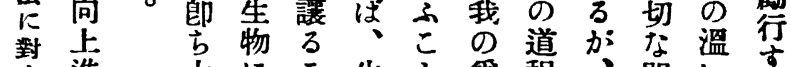

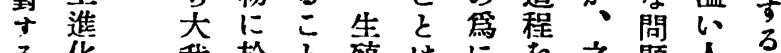
了化我於之殖は学之題人方

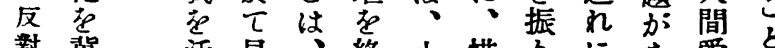

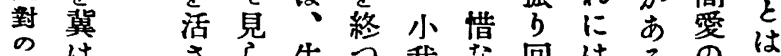
反はさら生う我な回はるのは

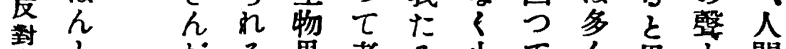
永交方了界老

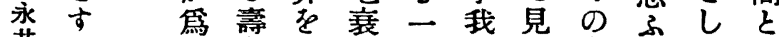

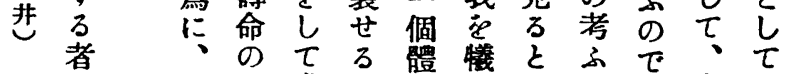

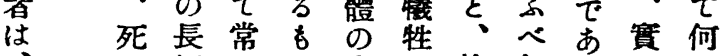

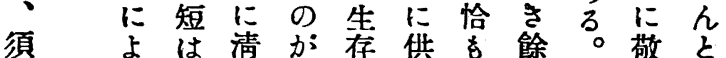

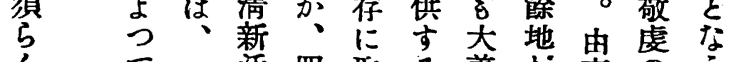

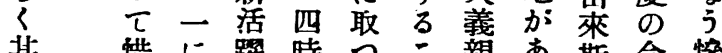
其徣に躍時うこ親あ斯念恎

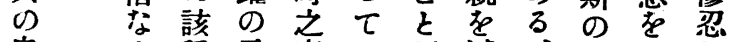
臬然元序は方:隇、如以な

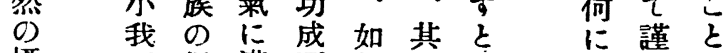

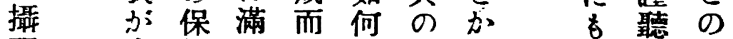
理奪續た退に根、慘吉様 に は

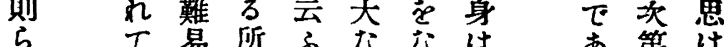
な居に以語るし鸿方第れ

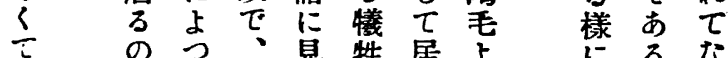

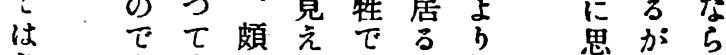

なあ決るるあの輕はは、な

らる定意栐るてく证い

なるさ義ににあ正るかと

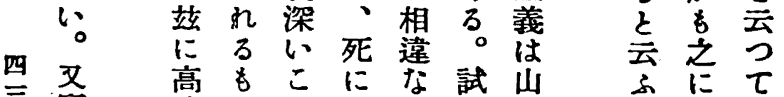

貴 嗃

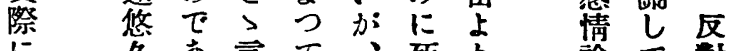

に市言て、死 り 論 $\tau$ 封

於 な

七 方皂な

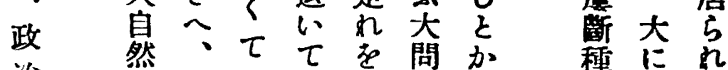

治 の生は、先題云法高乃

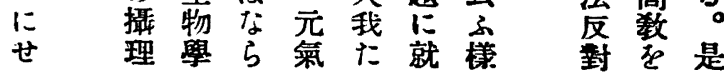

なにい探 現

浯たが代

等 らし

而 は 5 政

し あ併 、留

$\tau \zeta し$ 祭

現 ゆ夫限法

四

在万れな舉

四吾問たくゃ

等 題 か 有 經

のにら万湾

有就去芸学

了:つは土

遺 吾てな臺

畗等、它

學 の 政 らな

の有治うう

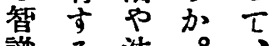

識現津其現

は在琶分代

斷の 經 か

種智濟 5 政

の識のな治

合の問い卢

法最題こ法

性 高蛋 $\Phi$ 律

娄

分儿切點湾

に物準分は㤎

語據恐恐用

$\supset$ し 3 引

$\tau \tau \neq<$ in

居、市遗市

万現放傅 居

の 在任に

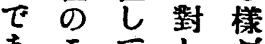

あこてした

万置衣か

捌譯分夫

Wに $5 n$

てはな等

行行以の

人かこ藇

よな之問

b加に

外で多す

はい分

贲な占名

な 名 な

以要遙こ

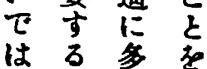


な問むに高外てて 教た根

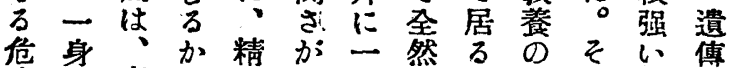

险卖直に神、步焎。如し力學

を救面過の遺も關飞何てをの

我ふし芯健傳踏心こに人有進

慢临てな否にみててな間つ步

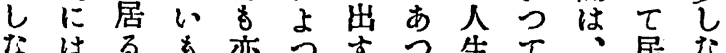

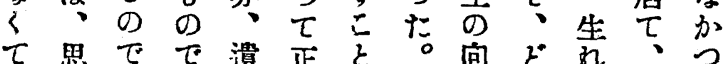

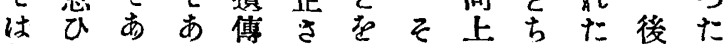

な切るるにし敢こ隻ら售笑時

らつ。こょく艺步にて的代

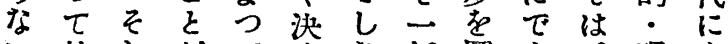

。外し がて定な切圖。環 あ

。科元明、世加のる、一境了

た手斷に約 $ら つ こ に$ 振切的 $\tau$

ひ衍種さ束れたを當向本影は

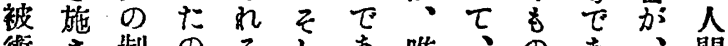

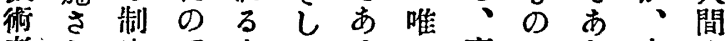

者な定でする。專でる夫心

自くのあの夫。外它あ、设身

人立如行而的外了全にの

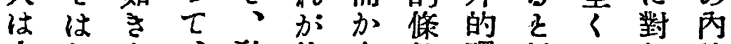

之な气、教後去件環信 の し 的

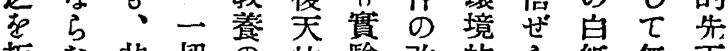

拒な其切の的驗改的 $ら$ 紙 無天

否いのの力に遺善問れて力的

し。現人は、傳全題 $\tau$ あなの

七 痛示生、榮學云に居つを素

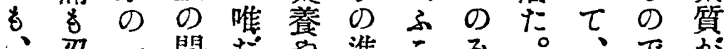

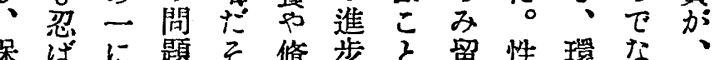

護な外はの飾にに意相境け如

者くな、莳等よのし近の机

のてら茲かでつみて翼筆はに

同はなにれ到て捉、相かな甚

意な心書た底活內遠、方し

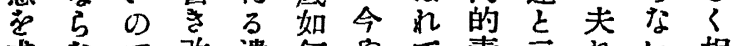

求なて 改遺何やて素云れ心相

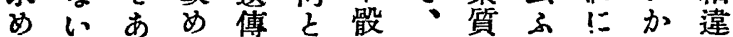

七。方質す政的孔一にせ

、血。れの市は治關子生關

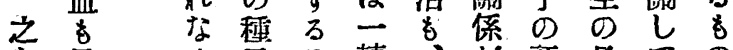

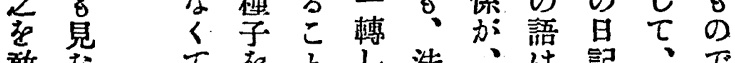

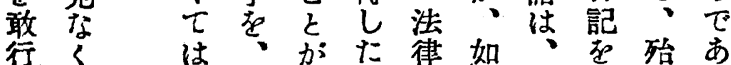

乙 な如出の娄何上書 $h$ 万

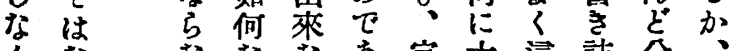

くななななあ宗大這誌分、

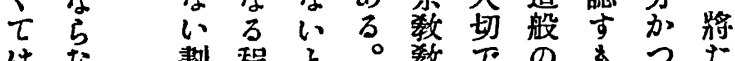

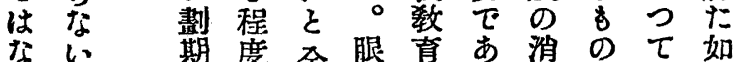

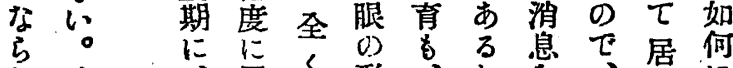

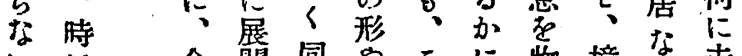

、に 今簡同吊こに物境な关

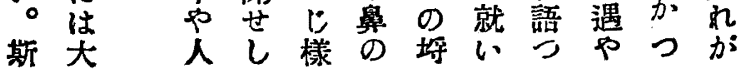

にる毙るよ。

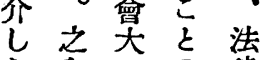

な袹 律

认是の雼に

㥞和生にせ

な察活全理

理南安全道著

五やし蜜を德

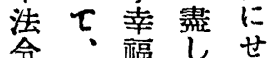

茫徒监立法

行 5 居山垶

はにとる宗子

れ個めか敉る

ろ人んのに反

な の が 如せ 對

ら權爲吉占 反

ば、利で觀—對

夫保護古主

はに、か;

本 の 究、斯

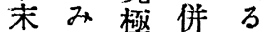

を 汲 の し 根

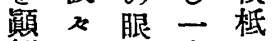

街之目步に

せ 乙㤎退立

蛋彼㑢

諭夫彼考俘

七肌在人居

あ か らてな

り篇見

-にしれ ह

冠社てばの

履會是、は

老老俔な

錯禍に人心。

せし、笵 し 權法

万民气利律

惡垶之保 の

法尼は護如

厄叠: す

な高改果四四

て㚾文竟見

なこ交了個

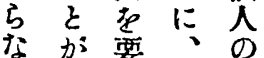

いあし之權

つな次利

ていに支

すの保

意あて等 
者形得法この正 か

の式方令文規當、愛

健的

康に它は出老業所芰

を見論正來設務諭部

埃れし當るけ三中斷

復ば、の思之因文種

碖せ、更業說 及》帝法

著し損に務く外霑國抵

噘九行九因種手夕法座

種こ雼てら諭石儿に談

法とた、者に行上會

にのる强爲のよ第つに

姜手己频吉說了公七於

子段之断行に斷、何け

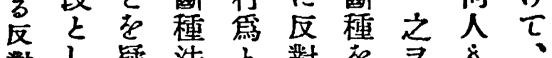

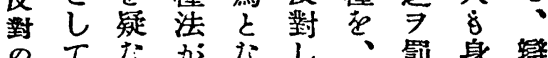

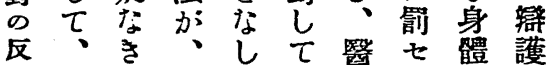

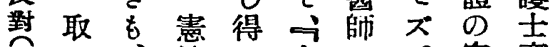

永つ、法心右の次安齋

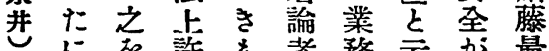

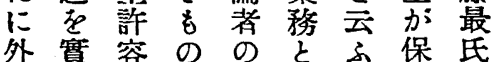

な質せに馀爲規障は

ら的らしはす定さ强

なにろて、にかか制

心考心、强於 あて 的

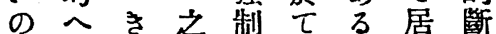

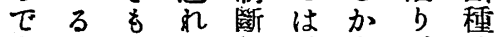

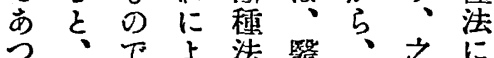

て夫なるが師國をは

、机心穴は蒙侵反

從は理、我一守對

己決由憲が般、者な

てしと法憲治法はる

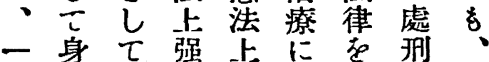

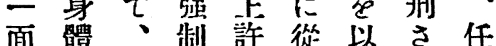

に㕝斷容事市れ意

は害師種さす、る斷

及守か法沉遺が種

了患をると傳法

患こ者制こ同病倣に

者との定と樣患しは

四若を身しをに者刑賛

四人目體得前、に法成

は的丞心提安對第な

之と切きとんし

にし開やしし斷吉

代た卞否元種五质

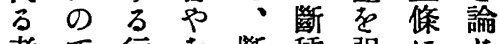

者厄行を斷種强にし

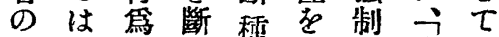

明なは諭行强し法居

示了之主雼势得令占

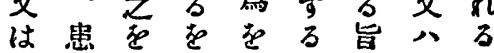

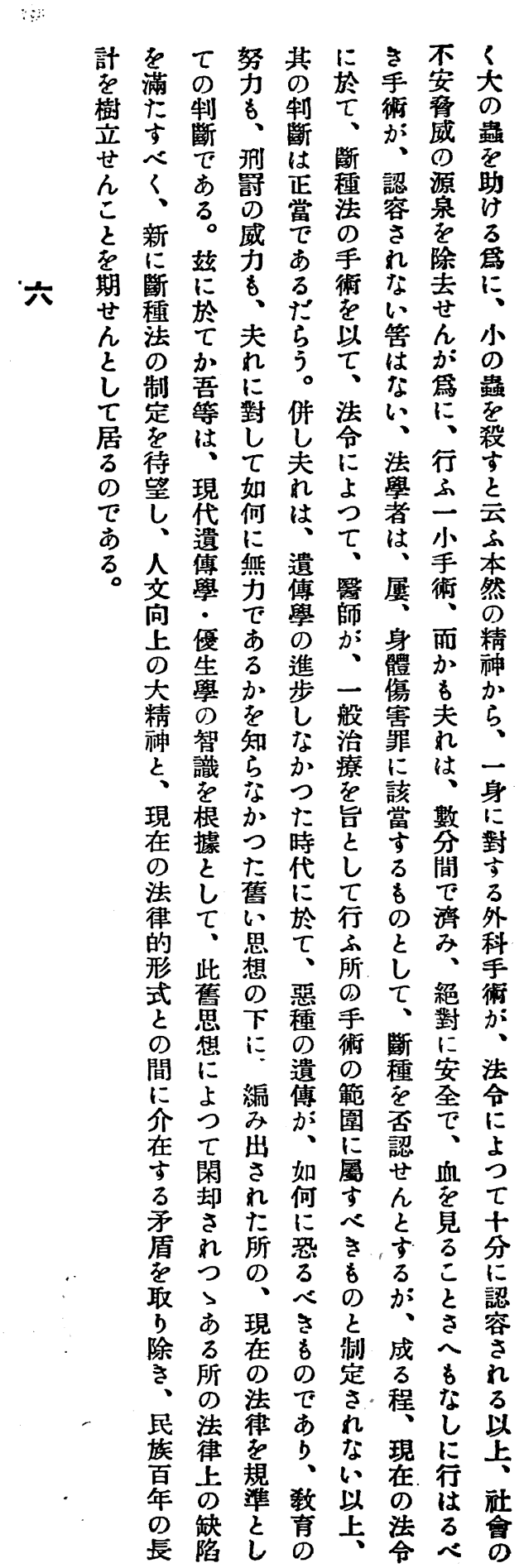




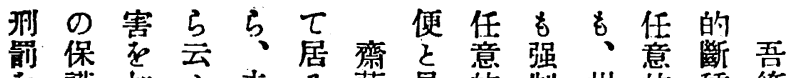
导護加及头了藤見的制州的種等 加にへなれ氐れ形的にの法は

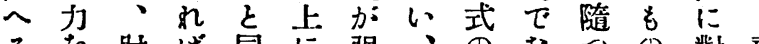

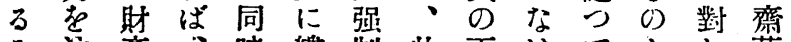
こ注產、時縷制此下㤝てをし藤 とぐ其に述斷點にれ趣す元 にる略の、し種に行ばをる。賛か

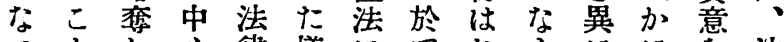

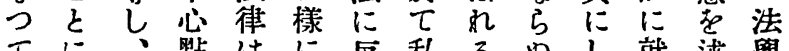

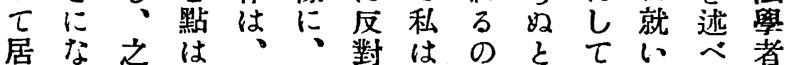
万つに 前擜法さ遺は思居てらの

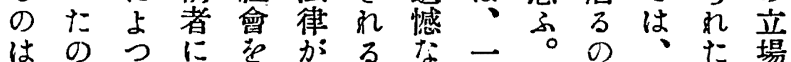

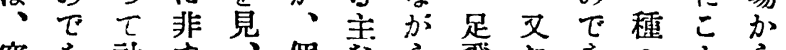

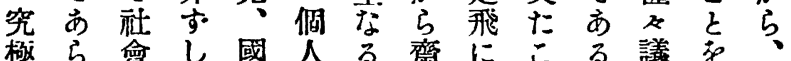

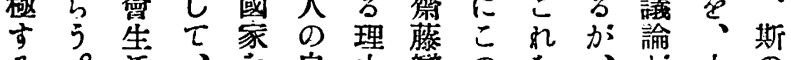

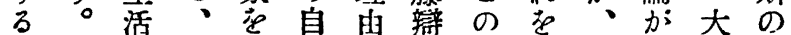

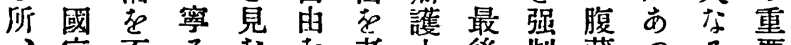
家不乃な考士後䠊藏つ方要 宗が安後く㧝察のの的なて喜な 数、不者七重卞御理に主、問 较法幸它は主意想行早現す題 育律にななるる見に心見にるに にに陷くら其を占到こ艮次關 上ょれてなの、從達之種第心

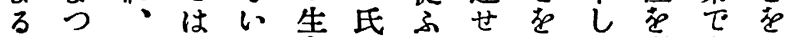
よて延なこ命 のこん理述賽あ拂 b、いらと財法之市百心行るは

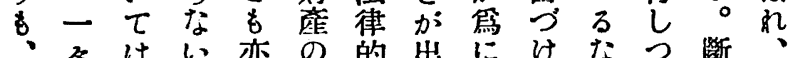

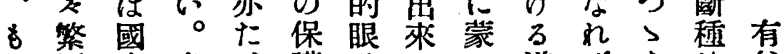
つ裖家多、護孔なる 道ばあ法谷

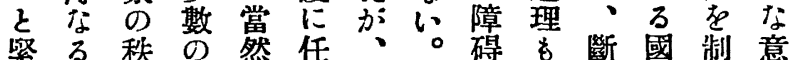

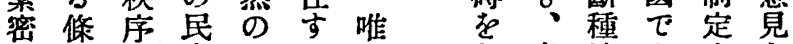

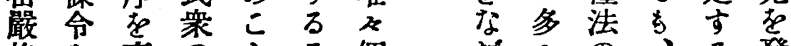

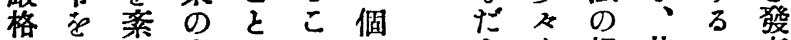

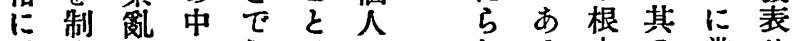
、定卞になは主は方本の當せ 國しるはく忽云にに精探うら

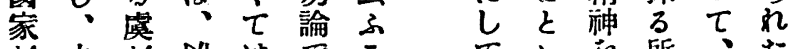

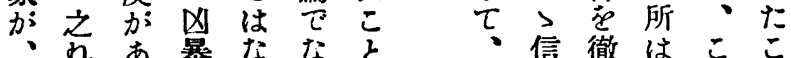

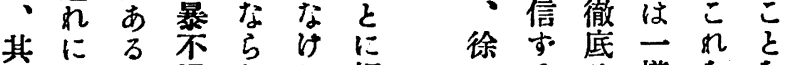

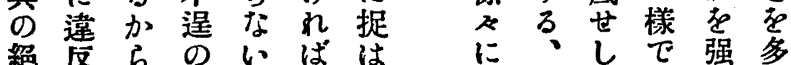
絕度 ら

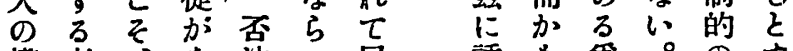
權者、あ法な居誘を䍃。のす 力息個つ律々る 導断に合もる

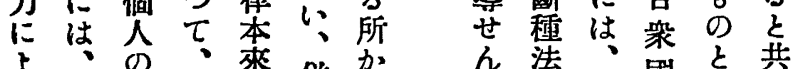
子、容生 生 の 併

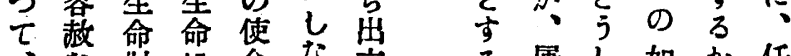

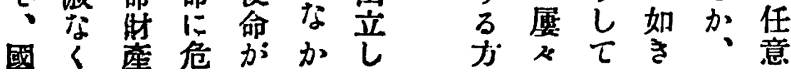

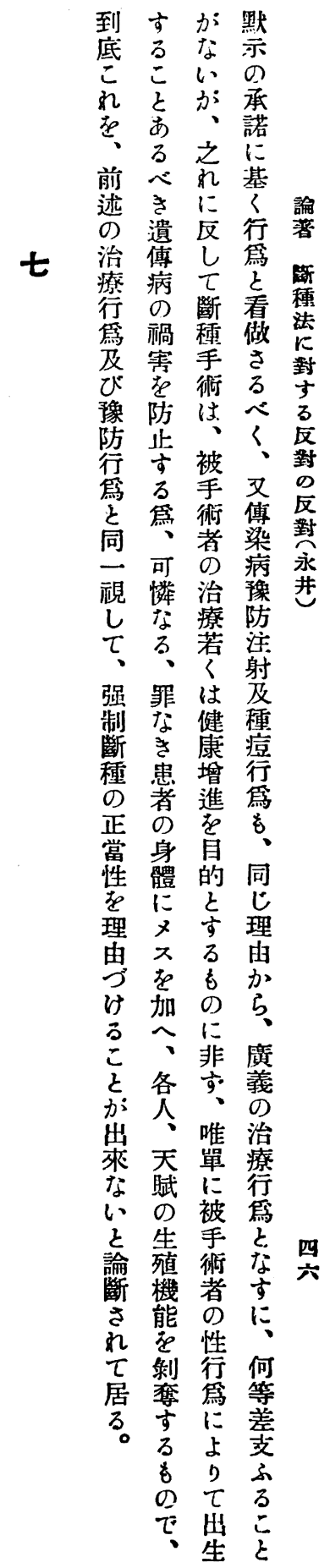

到士 加默

-

的方承

小娄諾

前心设基

の遺反行誈

療病它断看 種

雼禍種做法

及害手さ䍌

豫防洁公

防步被!、對

䉆 手 又

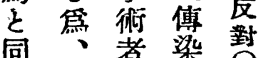

二可治病永

乙な療防

七当若

强罪は及

制な健 種

種患增行

者進 鳥

賞身貝

䣓 的 同

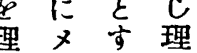

豈不方的

加

、韭废

各 す。義

出 唯 沿

天單 療

、の被第

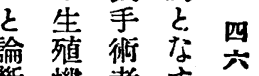

さ能のに

$\tau$ 制行何

居奪 第 


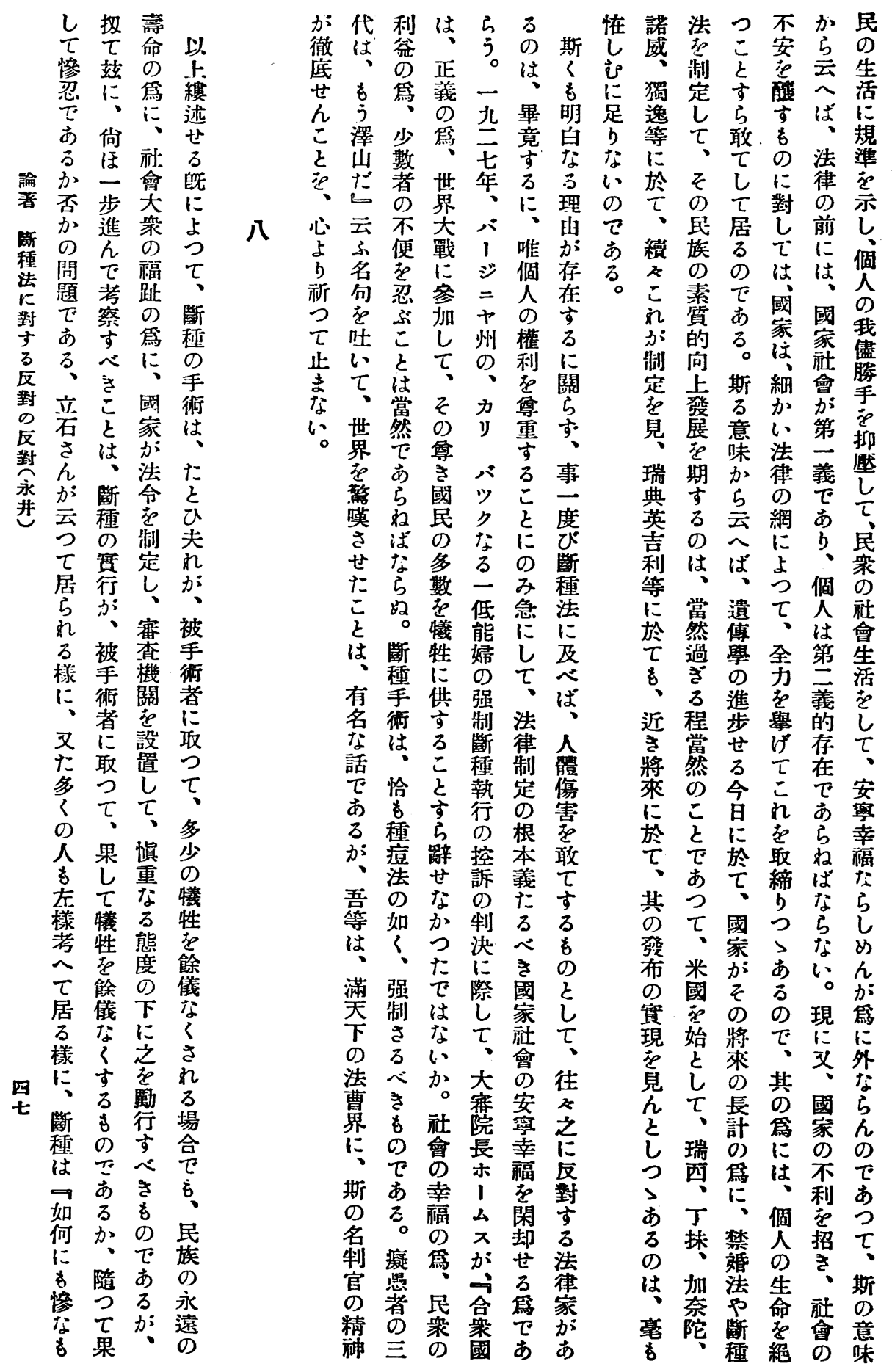




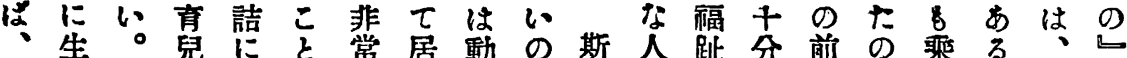

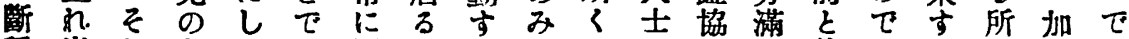

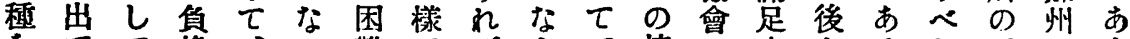

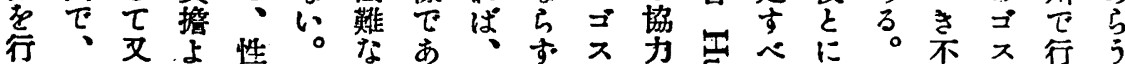

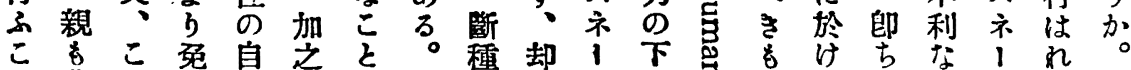

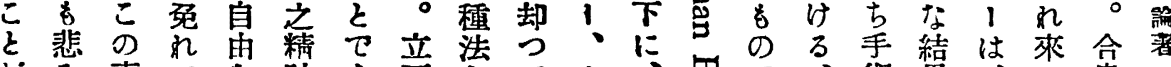

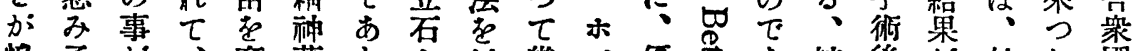

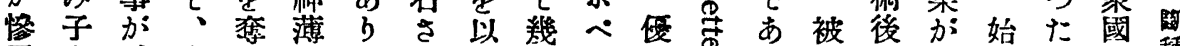
忍る、安ふ弱、ん多, 生罗る街の市はのに種

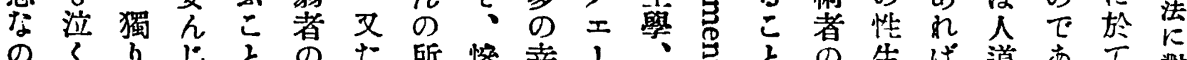
のく

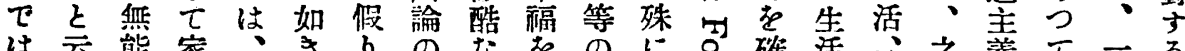
な云劣庭夫き、に

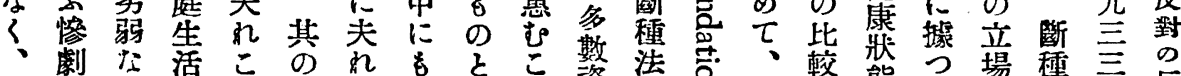

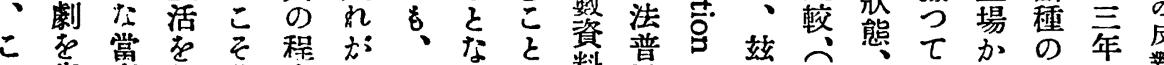

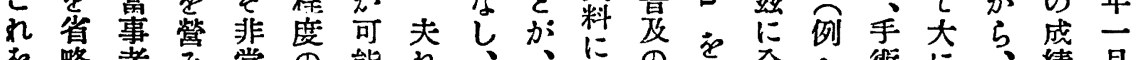

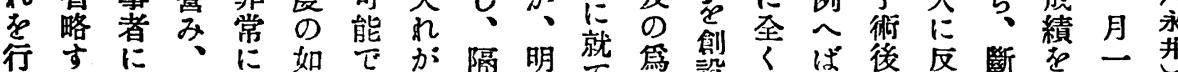

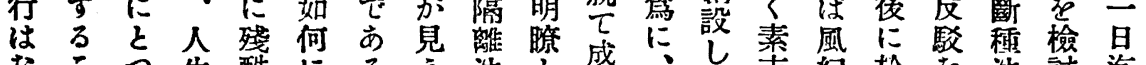

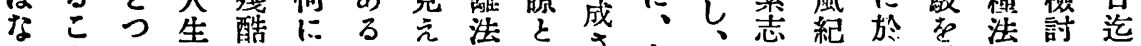

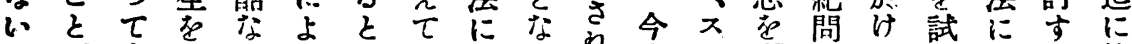

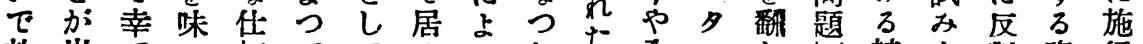

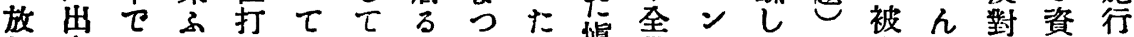

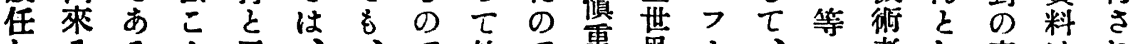

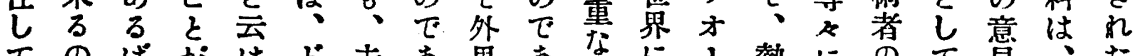
てのばがはど夫あ界あ研向1熱にの見、た 置はか出なう跨るとる研向ド烈就感、灾加所

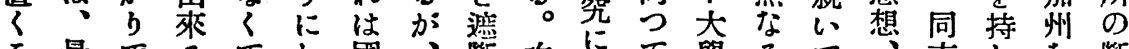

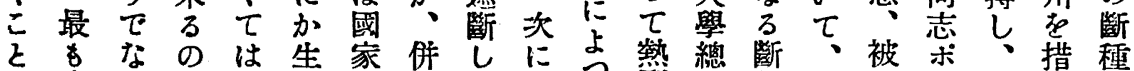

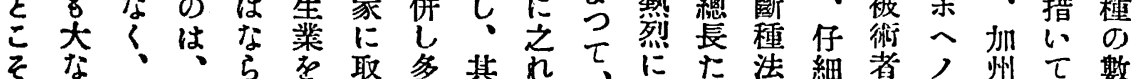

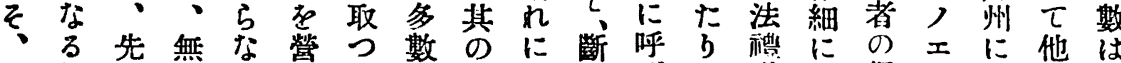

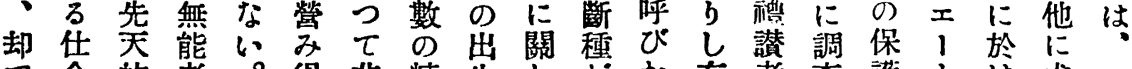
$\tau$ 合的者。得非精生し糹加有者查讙々沪求一

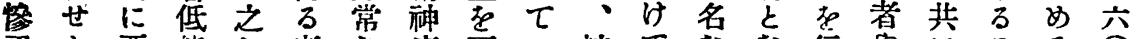

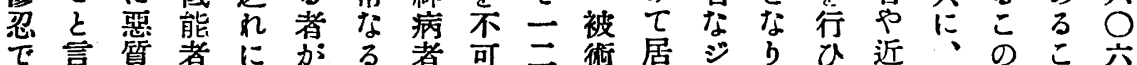
あはのに反あ負节能の者るョ、、親あ大六 るな遺對しる握低な主にの几私其のら切が のく傳すてにて能らな對で財方所ゆな出に

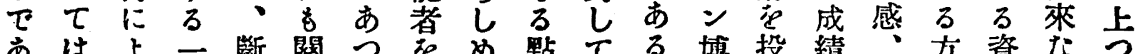

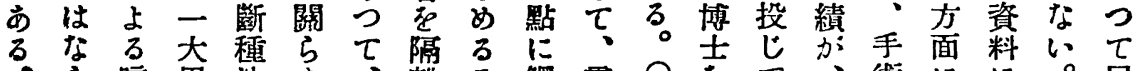

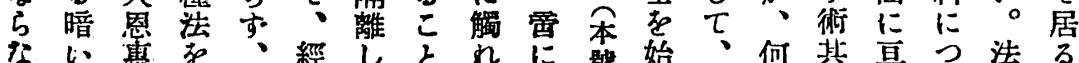

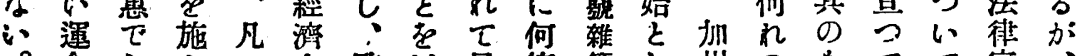

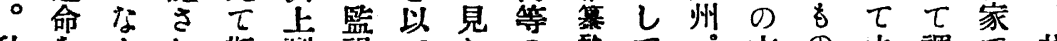

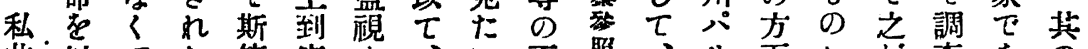
共以 $匚$ 等底夺、心不照、サ面〉方查ある かて、は後の行る理。利多デに安吟をh中 ら此な人想多蛋數 寸於危味行博牛

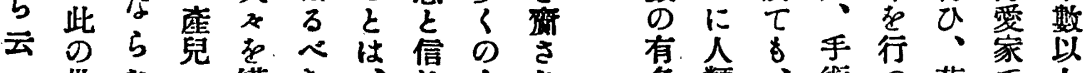

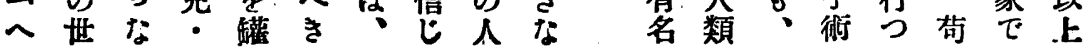




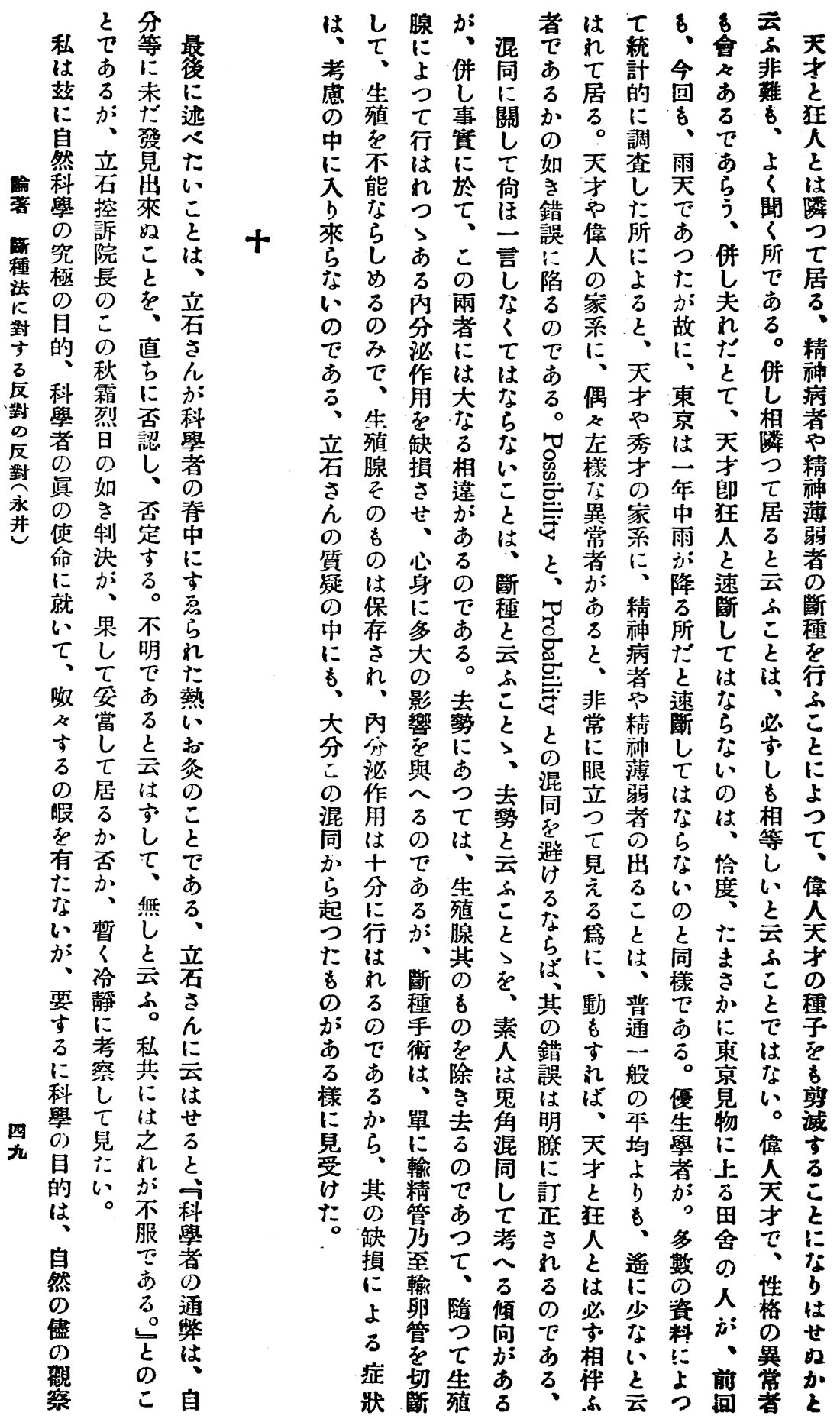




\section{科事な $\therefore$ 筫度 ある科者}

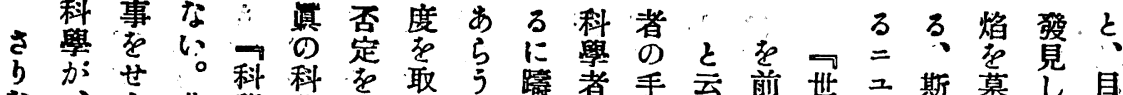

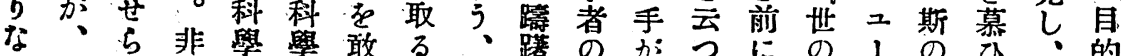

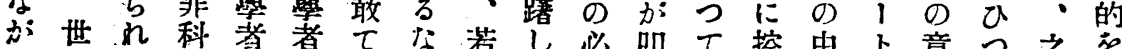

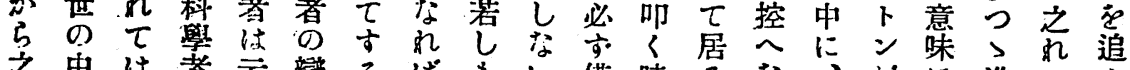

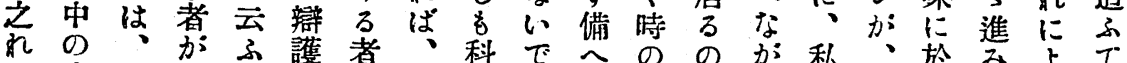

全飞政穴蒦

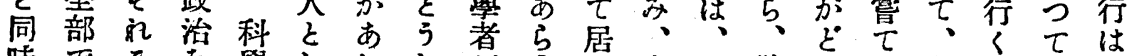

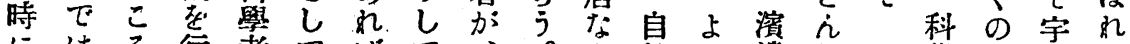

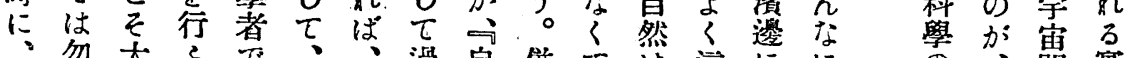

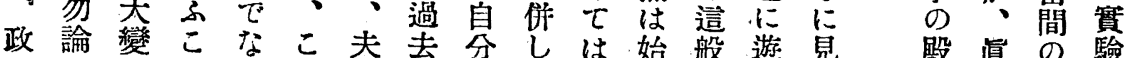

治な网變こ

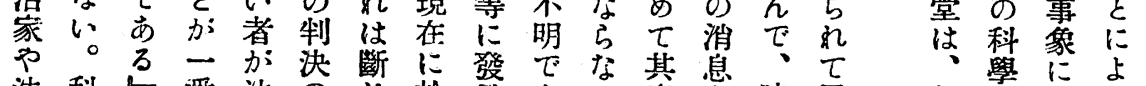

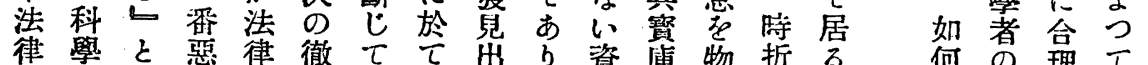

家者云い苑回宜見來解格の語滑办何能的!

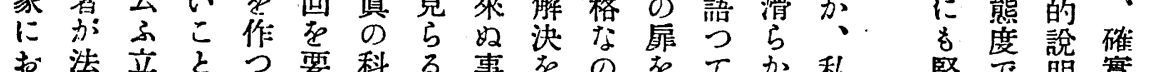

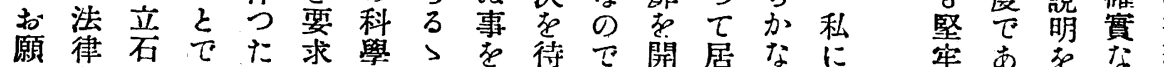

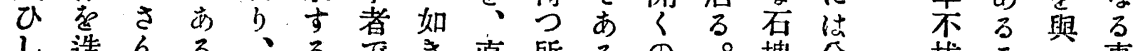

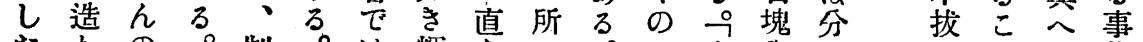

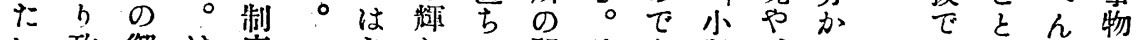

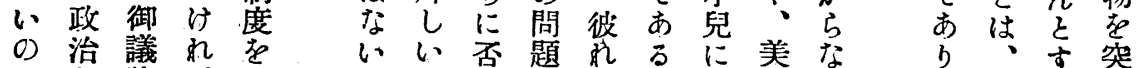

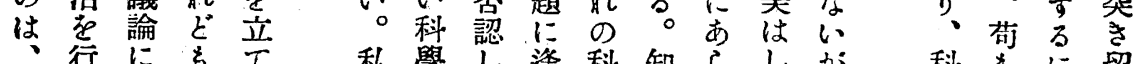

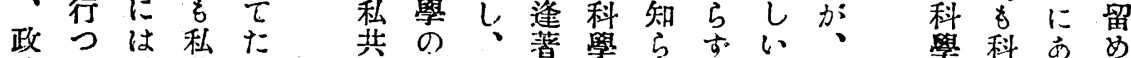

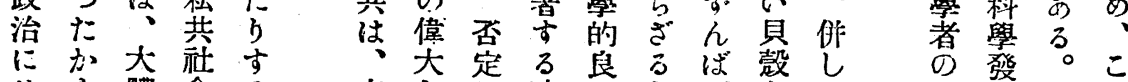

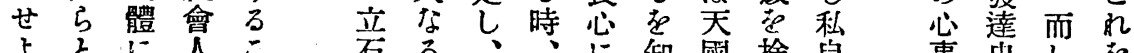

小元に全於

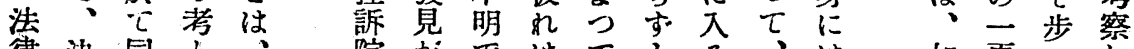

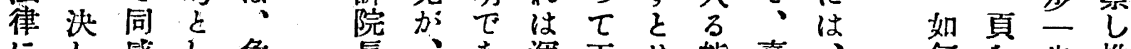

にし 感し危長、あ渾正せ能喜、何を步推

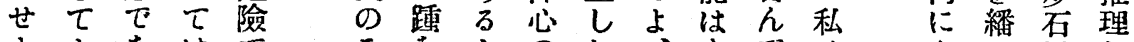

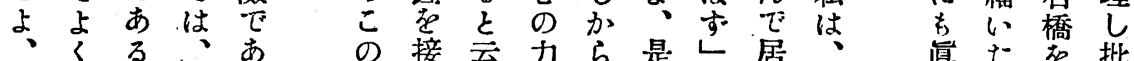

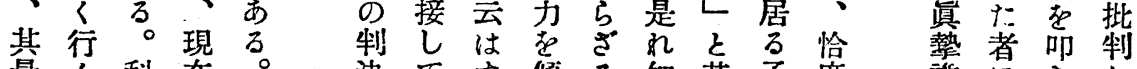

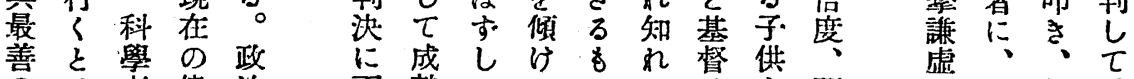

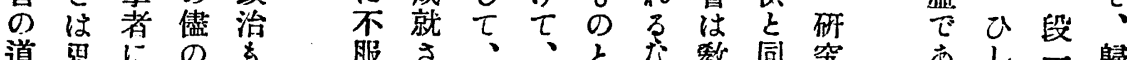

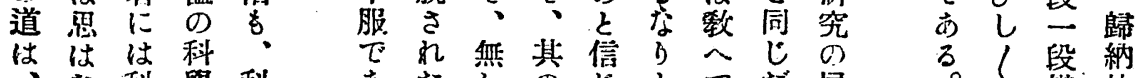

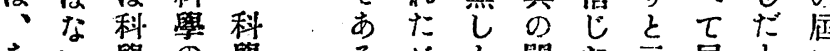

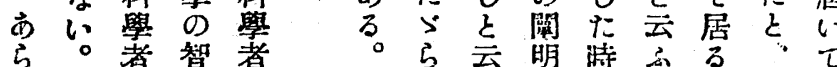

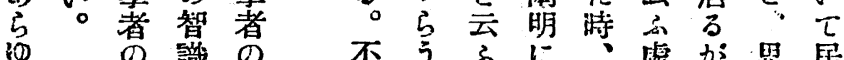

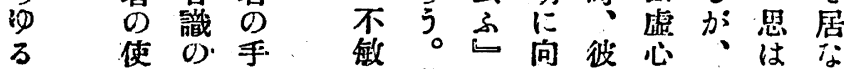

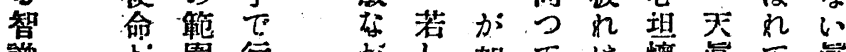

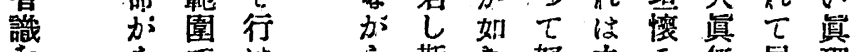

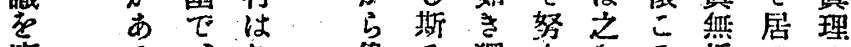

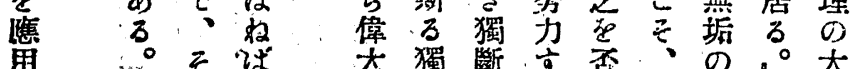

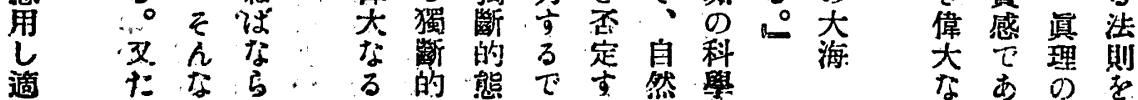

る人段納

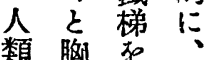

○党踏通

誇 打 み 有

$\varepsilon \rightarrow 1$ 普

方所め遍

ヘ $て な$

き筫、方 


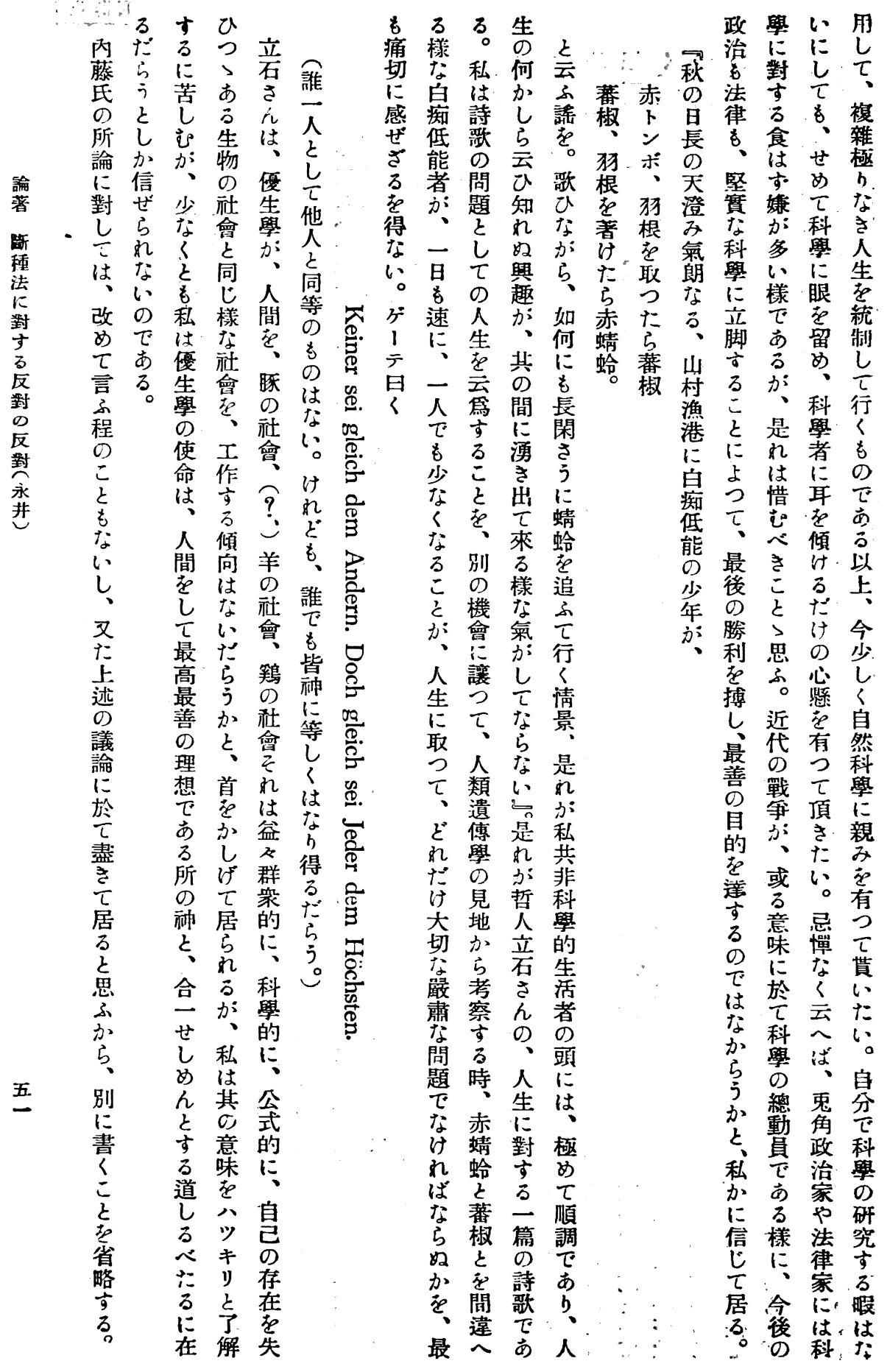




\title{
Kritik über die Oppositionen gegen Sterilisation.
}

\author{
Von
}

Dr. H. Nagai.

Wie es in vielen Ländern der Fall ist, so hat man auch in Japan die Stimme gegen Sterilisation von mehren Seiten, namentlich von Juristen, erhoben.

Kürzlich fand im Nagoya-Zweig-Verein der Gesellschaft für Japanische Rassenhygiene ein Kolloquium über das neu in Kraft tretende Sterilisationsgesetz der Nazi-Regierung statt. Darüber sprach Herr K. Tateishi, Chef $d \mathrm{~s}$ Oberlandesgerichts und äusserte dabei Bedenken gegen das Sterilisationsgesetz teils aus philosophischen, teils juristisch-sozialistischen Gründen. Da seine Sti mme in gewissem Sinne als ein Vertreter der Antisterilisationsmeinungen anzusehen ist, möchte ich im Vorliegender meine Ansicht hie, gegen aussprechen.

Nach Tateishi ist es eine besondere, nur in menschlicher Gesellschaft sichtbare Glückseligkeit, dass sich angeborene Blinde, Tau'stumme und sonstige Krüppel ruhig und getrost ihre Existenz erfreuen. Demgegenüber mö hte ich sagen, dass es ja gewiss der Stolz $\mathrm{d} / \mathrm{r}$ zivilisierten Menschen ist, den Unglücklichen gegenüber barmherzig zu se:n. Man muss sich abər dabei immer bəwusst sein, "gegenwärtiges Sein" und "künftiges Vorkommen" scharf zu trennen. Schon geborene Minderwertigen muss man Schütz und Fürsorge angedeihen lassen, jedoch gibt es keinen einzigen Grund, deswegen die Geburt weiterer Minderwertiger von newem zu begrüssen.

Auch sagt man oft, dass kaum 30 Jahre verflossen sind, seitdem die 
Eugenik wissenschaftlich begründet ist und daher auch ohne Eugenik unsere Vorfahren sind vom Anthropomorphen zu Homo Sapiens, vom Barbaren zum Zivilisi rten heranbildeten. Was sagt denn die Eugenik hierzu? Aus den ersten Blick scheint dieser Einwand ganz zutreffend. Man muss aber nicht vergessen, dass es in anderen Zeiten andere Männer gibt. Obwohl die Eugenik in alten Zeiten, wo die Selektion auf die $v$-rschiedenen Menschen'eben richtig einwirkte, unnötig gewesen war, ist sie bəi den jetzigen Kulturvölkern geradezu unentbehrïch, da ja mit dem Kulturfor'schritt der altruistische Gedanke immer wieder praedominiet und dementsprechende sozia'e Interessen stark bətrieben und infolgedessen statt der richtigen Selektion sehr oft und unbewusst Kontraselektion zur Ausführung kommt. Unter solchen Umständen ist das einzige unumgängliche, traurige Schicksal die Rassendegenerat on und der Völkertod. Die alten Kulturvölker wanderten einst auf diesem fürchterlichen Wege und eilend folgen auch die jetzigen zivilisierten Menschen ihren Spuren. Ein Wort "Proletaria" überzeugt dies genügend.

Man tadelt die Sterilisation deshalb, weil die menschliche Erblichkeitslehre immer noch zu rückständig sei, als dass daraus das Sterilisationsgesetz entworfen werden könnte. Demgegenüber möchte ich aber darauf hinweisen dass die Erblichkeitsforsc'ung des Menschen neulich schwungweise Forts hritt gemacht hat, und dass namentïh für die Ve:erbbarkeit einig $\mathbf{r}$ Fsychcson un 1 des Schwachsinns der feste Beweis geliefert wurde. Au: Grun 1 dieser Kenntnisse kann man jetzt getrost negative Eugenik bətreiben. Andererseits muss man ja zugestehen, dass in den menschlichen Vererbungen noch viel Dunkles bleibt. Aber, so möchte ich fragen, gibt es denn ein einziges Gebiet im Menschenle’en, wo alles endgültig klar gemacht und kein Rätsel mehr besteht ? In dər Rechtswissenschaft, Politik, Ek วnomie u. s. w. würde es gewiss noch mel:r Dunkles geben als in der mencshlichen Erblichkeitslehre. Trotzdem kann man natürlich nicht ohne Gesetz und 
Verfa sung abwarten, bis alles auf ciesem Gebiat geklärt ist. Man muss sich camit begnügen, alle Handungen durch gegenwärtige höchste Kenntnisse richtig $\mathrm{zu}$ gestalten.

Juricten und Soziologen verwerfen oft das Sterilisationsgesetz als cinen Verletzungseingriff gegan den menschlichen Körper und als kalte, grausam? Behandlung der Minderwertigen. Dieser Enwand ist aber nicht richtig. Denn es ist ein biologisches Grundgesetz, der Spezies willen das Individuum schonungs'os $z u$ opfern und dadurch vergegenwärtigt sich der grosse Fortschritt im Lebewesen. Im Grunde genommen muss es auch im Menschenleben so sein. Zuerst die Rasse, dann $d s$ Individuum als rächstes. "Ich" muss d rch "wir" verdrängt werden. Das Gesetz. schützt das ind'viduelle Leben nnd Vermögen mit $\mathrm{g}$ 'osser Sicherheit, um damit richtig dis Ordnung und Wohlfahrt des Staats $z_{1}$ halten. In diesem Sinne findet sich das Sterilisationsge:etz im vollen Recht des "Raison d'ètre". 'Um individuelles Leben zu retten, ist die chirurgische Operation oft mit grossem Risiko gesetzlich voll anerkannt. Warum denn also der Sterilisationsprozess nicht, der um allgemeiner Wohlfahrt und Rassengesundheit willen erbschädliche Keim zu vernichten strebt und gefahrlos, fast unblutig ausgeführt wird?

Juris'en betrachten oft das Sterilisationsgesetz aus dem Grunde verfassungswidrig, weil bei ihnen in folgenden Funkte Missverständnisse bestehen.

1. Sie sehen nur das Individuum und vergessen die Rasse.

2. Sie batrachen oft die Sterilisation a's Strafe und verstehen nicht das eugenische Motiv.

3. Sie verwechseln sehr oft Sterilisation mit Kastiation und beschuldig an dies als gro:sen Eingriff gegen das Menschenrecht. Viele beschuldigen die Sterilisation : ls eine grausam? Handlung. Aber in Wirklichkeit ist die Steri.isation nicht nur nicht grausam, sondern tine 
grosse Wohltat. Denn Minderwertige, die sonst kaum in die Ehe treten könnten, vermögen nach der Operation getrost Ehe zu schliessen und können sich des familiellen Lebens erfreuen, ohne durch Geburt von Nachkommen ihresgleichen materiell und psychisch gedrückt zu werden. Zugleich kann man damit den unschuldigen Sprössling vom bevorstehenden harten, dunklen Schicksal ausschalten und Staat und Volk ganze Summen von materiellem Konsum ersparen und vor unabschätzbarer psychisches Sorge b. wahren. (Autoreferat) 